\title{
Morphological and phytochemical analysis of leaves and stems of Tetrapterys multiglandulosa CAV.
}

\author{
Gilberto Gonçalves Facco*1, Eloty Justina Schleder ${ }^{2}$, Natalia Yoshioka de Vidis ${ }^{3}$, Maristela Halverson ${ }^{3}$, \\ Rosemary Matias ${ }^{4}$, Marcos Barbosa-Ferreira ${ }^{1}$, Doroty Mesquita Dourado ${ }^{4}$, Carlos Eurico dos Santos \\ Fernandes $^{5}$
}

\author{
${ }^{1}$ Graduate Program, Mestrado Profissional em Produção e Gestão Agroindustrial, Anhanguera - Uniderp \\ University, Campo Grande, MS, Brasil \\ ${ }^{2}$ Anhanguera - Uniderp University, Campo Grande, MS, Brasil \\ ${ }^{3}$ Anhanguera - Uniderp University, Campo Grande, MS, Brasil \\ ${ }^{4}$ Graduate Program, Meio Ambiente e Desenvolvimento Regional, Anhanguera - Uniderp University, \\ Campo Grande, MS, Brasil \\ ${ }^{5}$ FAMEZ/UFMS, Campo Grande, MS, Brasil
}

Abstract

This study aimed to carry out morphoanatomical, histochemical and phytochemical analysis of leaves and stems of Tetrapterys multiglandulosa Cav. (Malpighiaceae), a native plant responsible for abortion and sudden death in beef cattle. Plant specimens underwent anatomical study, in which leaves and stems were dried and ground with aqueous and ethanol extracts subjected to histochemical and phytochemical analysis. Anatomical observation of vegetative organs detected the presence of simple columnar cells in the adaxial epidermis, palisade mesophyll, parenchyma with a layer of cells and paracitic type stomata. Stem cross-sections presented circular section, single layer (uniseriate) epidermis with thick cuticle and Malpighi's trichomes, the phelogen was in differentiation. The cortex showed angular collenchyma, parenchyma with exogenous channels and druse shaped calcium oxalate crystals. Phytochemical tests of aqueous and ethanol extracts of leaves and stems indicated the presence of phenolic compounds, tannins, flavonoids, saponins, alkaloids and cardiotonic heterosides. Potentially phytotoxic secondary metabolites evidenced in the leaves and stems, including saponins and cardiotonic heterosides were correlated with clinical signs observed in intoxicated animals.

Keywords: Cardiotonic heterosides; Cattle; Digoxin; Malpighiaceae; Toxic plant.

Introduction

In Brazil, Tetrapterys multiglandulosa Cav., is a plant native to the Atlantic Rainforest biome (Pott et al. 2006), occurring principally in the Resende e Rio das Flores region of Rio de Janeiro state, as well as in the counties of Guaratinguetá and Lorena in São Paulo state (Carvalho et al., 2009). Despite limited presence outside this Southeastern region of Brazil, cases of intoxication have been reported in the Midwest state of Mato Grosso do Sul (Carvalho et al., 2006). It is popularly known as "red vine" or "iron vine", has lush, bright green leaves, with yellow, panicle inflorescence, which when bearing fruit take on a reddish-brown coloration (Tokarnia et al., 2002).

T. multiglandulosa belongs to the Malpighiaceae family, within approximately 75 genus and 1,300 species, distributed in tropical and subtropical regions of both hemispheres. In Brazil there are 45 genus, with some found in the Midwest region (Souza and Lorenzi, 2012). Taxonomical classification of Malpighiaceae is complex, due to its magnitude, with identification at the genus level based solely on morphological characteristics and considerable similarity between species (Anderson, 2001).

While $T$. multiglandulosa is suspected as the causative agent in cases of bovine and ovine intoxication, few studies detailing the physical characteristics of this plant have been carried out in Brazil. Evidently, secondary metabolites may be responsible for cases of spontaneous abortion as well as sudden death in cattle, sheep and goats (Carvalho et al., 2006; Souza et al., 2015). In these cases, cardiac coagulative necrosis is the principal lesion encountered in fetuses, young and adult animals. Thus, a study encompassing analyses of definitive physical characteristics of the plant, as well as identification of possible secondary metabolites involved in the pathogenesis of intoxication was indicated.

The objective of the present study was to carry out morphoanatomical, histochemical and phytochemical analysis of leaves and stems of $T$. multiglandulosa Cav. collected from the border between the Midwest and the Southeast regions of Brazil, in which this plant was believed 
to be responsible for an outbreak of intoxication and death of cattle.

\section{Results and Discussion}

The leaf blade demonstrated an unstratified epidermis with thick cuticle, glandular formations, trichrome on the abaxial surface, dorsiventral mesophyll with one to two cell layers of palisade parenchyma and three to four strata of lacunar parenchyma, druse and prismatic crystals. Additional leaf structures include; a median plane-convex vein, formed by collateral bundles framing of an open arch, enveloped by a sclerenchyma. From a frontal view are visible paracytic stomata on the abaxial surface, epidermal cells with irregular contours and varied shapes. These structural characteristics are like those observed by Mamede (1993) in species of the Malpighiaceae Family, which included high cells in the adaxial epidermis, dorsiventral mesophyll, one cell layer of palisade parenchyma and paracytic stomata.

Stems transversal sections demonstrate a circular shape, unstratified epidermis with thick cuticle, Malpighian trichomes and differentiated phelogen. The cortex is characterized by angular collenchyma, parenchyma with exogenous channels, calcium oxalate crystals in the form of drusen, prismatic fibers in the phloem region and a continuous collateral vascular ring. Within the vascular system, the medulla is composed of parenchyma tissue, which in some areas, during growth, was apparently absorbed. Histological images from stem and leaves cutting are presented in Fig. 1.

Utilizing histochemical methods, starch was identified in stem dispersed in the cortical parenchyma forming an amiliferous sheath surrounding the vessels (Fig. 2a), while in leaves starch was dispersed within the mesophyll, especially in the palisade parenchyma. Phenolic compounds were revealed in stems, especially in the cortex and in conductive vessels, in while in leaves these compounds were found in the phloem region and in the mesophyll (Fig. 2b). Reducing sugars were found both in the cortical region and in the vessels and medulla of plant stems, in leaves the reducing sugars was observed as well as in all leaf tissues and glands (Fig. 2d). Mucilage was evident in the stem cortical parenchyma (Fig. 2e), in leaves near the phloem and in central and secondary veins. Lipid substances were observed in the cuticle and the cortex (Fig 2c), as well as in the leaf cuticle and glands. Santana et al. (2013) found similar results studying Byrsonima coccolobilifolia leaves, including the presence of lipids and phenolic compounds in foliar mesophyll cells.

The chemical constituents detected in leaf and stem, using extracts $\left(\mathrm{ExtH}_{2} \mathrm{O}\right.$ and ExtEtOH) indicated a similar diversity, including nine different classes of secondary metabolites. However, ethanolic, hydrophilic $(\mathrm{OH})$ and hydrophobic (Ethylene Group) extracts, were more efficient for extraction of phenolic derivatives, tannins (100\%), flavonoids (50\%) and steroids $(25 \%)$ in relation to aqueous extract, which is a polar solvent (Table. 1).

The Malpighiaceae family of plants is known to contain terpenoids, essential oils, alkaloids, phenolic substances, polyphenols, quinones, flavonoids, flavonols and flavones, coumarins and tannins (Souza and Lorenzi, 2012). Specifically, in leaves of T. multiglandulosa, Melo et al. (2001) detected the presence of flavonoids, condensed tannins, quaternary alkaloids and steroids. In the present study, the presence of these substances was confirmed, corroborating the literature.

Rodríguez et al. (2008) detected monoterpenoids, alkaloids and saponins in the aqueous extract of leaves and stems of, T. styloptera. Ethanol extracts contained triterpenes, monoterpenoids and alkaloids. Monoterpenoids and alkaloids were also detected in T. mucronata. The fact that these metabolites were also detected in the current study demonstrates that these substances are common characteristics of this genus.

Also, the present study revealed that many tissue structures are common amongst species of the Malpighiaceae Family, as observed in the study by Coelho and Spiller (2008), suggesting that these characteristics could be used as a diagnostic tool for $T$. multiglandulosa identification. Regardless of extractor solvents utilized the phytochemical observations detected the presence of phenolic compounds, mainly in the cortex and conductive vessels of stems and in phloem and mesophyll of leaves. Histochemical tests provided evidence that stem and leave tissues are the fundamental sites for synthesis and/ or storage of phenolic compounds, a chemical group that merits further study.

According to Castro et al. (2009), secondary metabolites are substances involved in plant defense, which are differentially expressed in qualitative and quantitative terms, from organ to organ and from species to species. Their concentration is determined by environmental influence and genetic control. Phenolic compounds are chemically heterogeneous secondary metabolites; including a wide variety of compounds, such as flavonoids, tannins, and benzoic and cinnamic acids. Idioblasts and epithelial cells that delimit cavities are the structures that secrete these substances, being present in almost all plants and found predominantly in vacuoles, cytoplasm or impregnated in the cell wall. These compounds can act as a simplastic barrier, which drives a morphological change favoring the appearance of the somatic embryos of the plant. In completely differentiated organs, the presence of phenolic compounds is related to defense mechanisms of the plant, such as protection against herbivory, attack by pathogens and microorganisms, desiccation, among others (Appezzato-da-Gloria and Carmello-Guerreiro, 2006).

Normally, common phenols in plants are not toxic, except for polymeric phenols, specifically tannins which can complex proteins in aqueous solutions (Simões et al., 2004). In plants, tannins present antioxidant activity due to the inactivation of free radicals. Tannin synthesis is related to the processes of cell growth and differentiation, and the degradation of these substances favors cell division, avoiding the oxidation of the vegetal material. They are biosynthesized directly from carbon metabolism and stored in plant vacuoles (Castro et al., 2009).

Starch is a polysaccharide and the main reserve of sugars in plant cells, with starch grains indicating high energetic metabolic activity, used to initiate and maintain the development of the plant, and useful in the acquisition of embryogenic competence (Torres, 2013).

The recurring presence of cardiotonic heterosides in other studies of plants from Malpighiaceae Family, including Mascagnia pubiflora (Nascimento and Habermehl, 1995), Heteropterys aphrodisiaca (Coelho and Spiller, 2008) and T. 

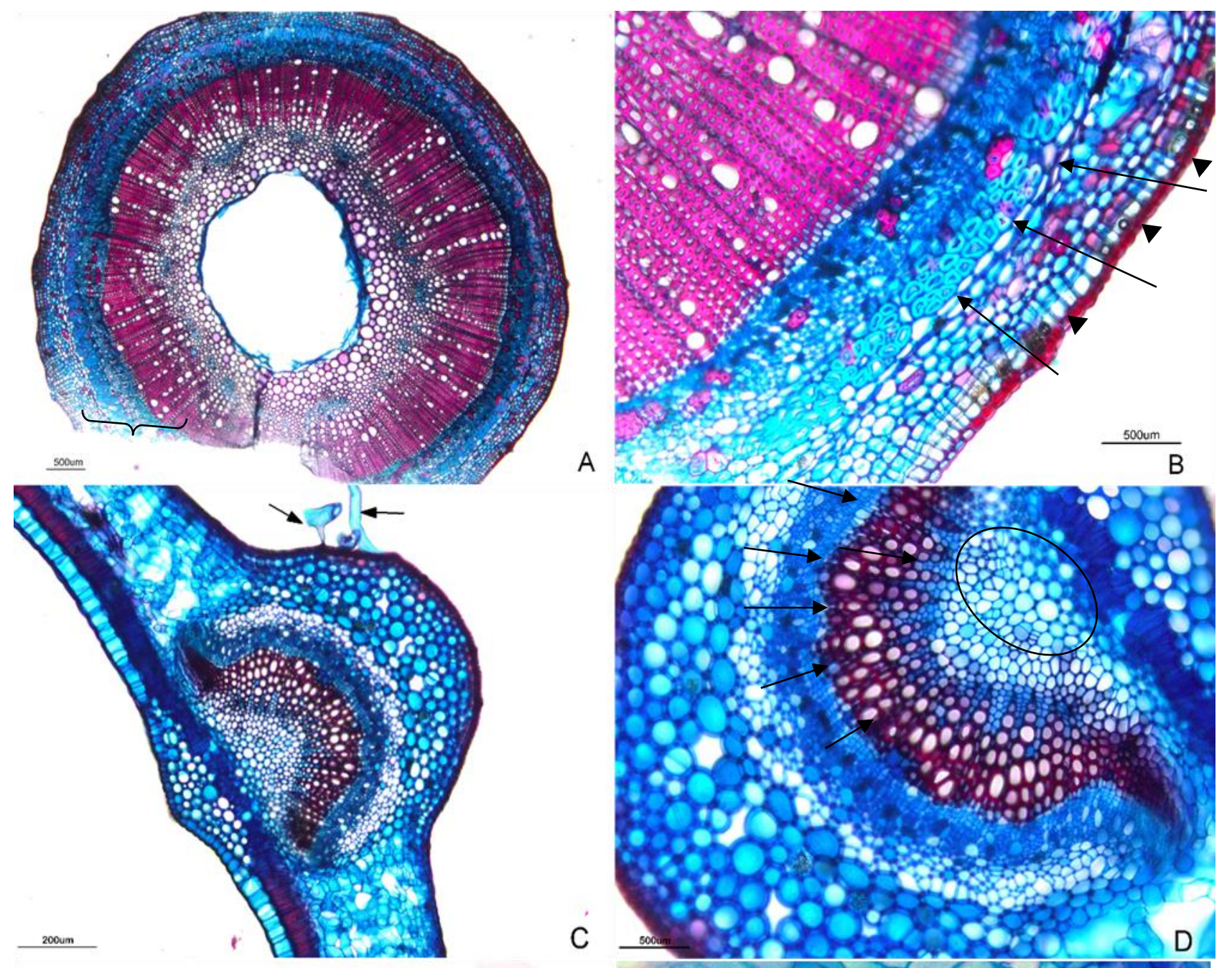

A
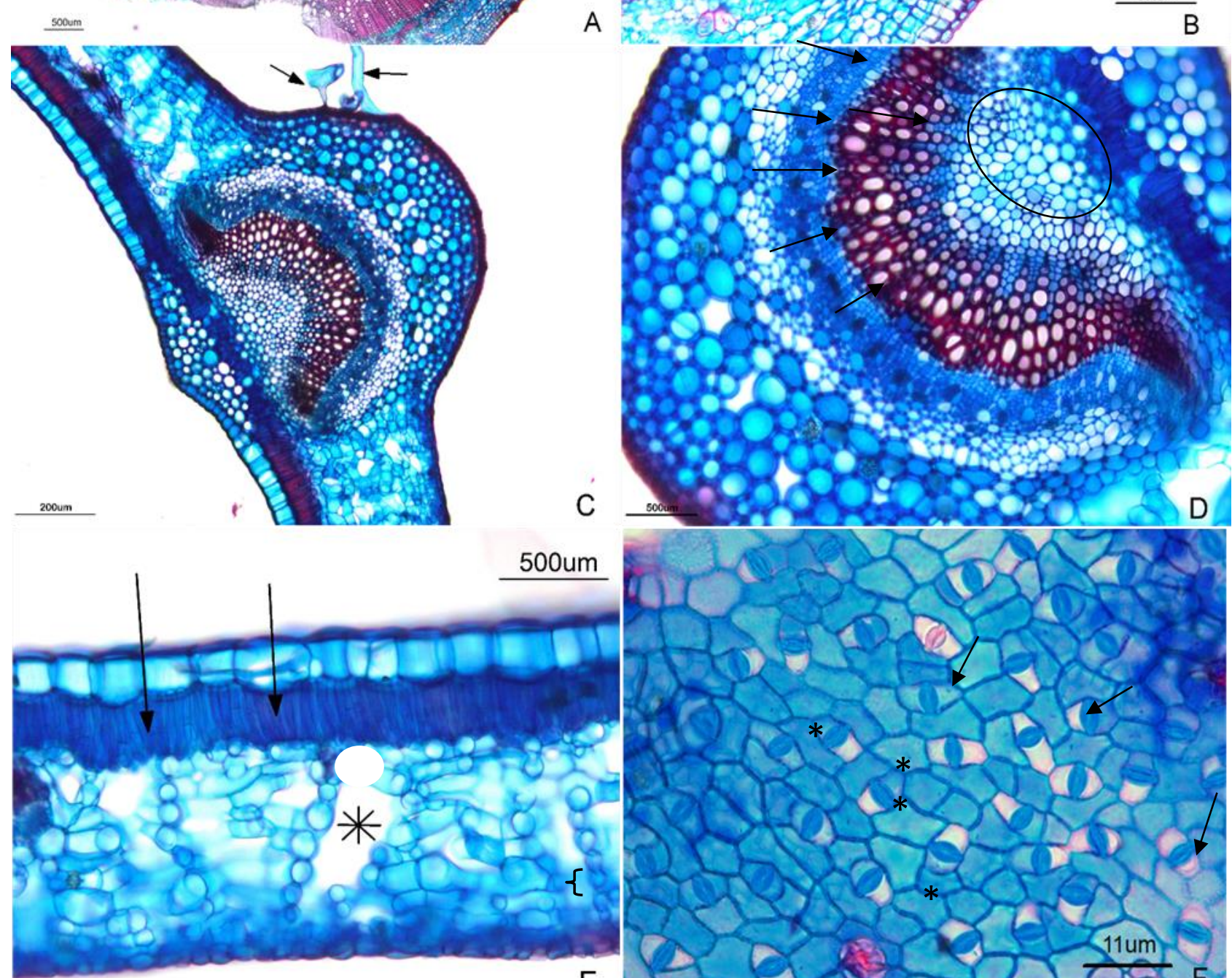

$\mathrm{E}$

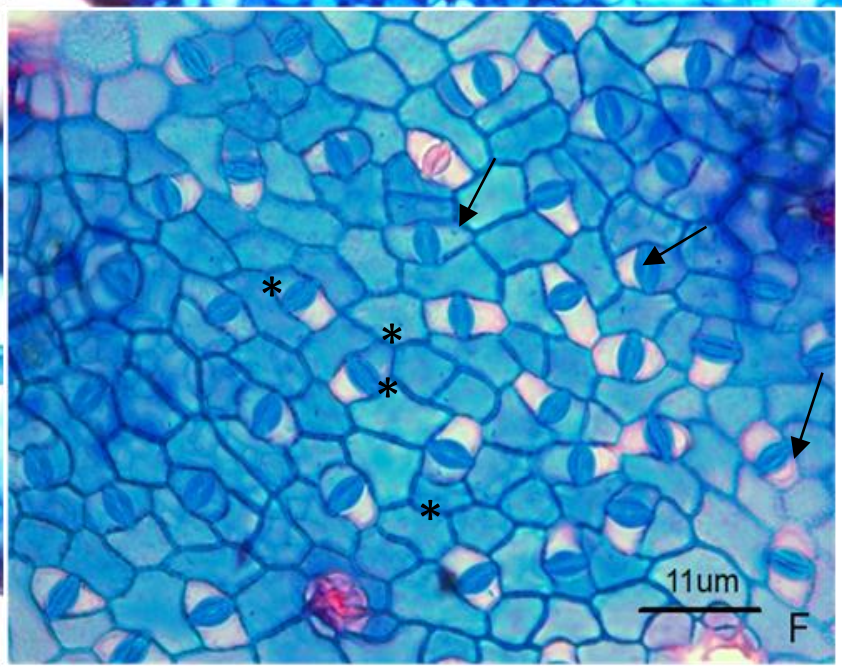

Fig 1. Light photomicrography of stem in transversal cutting of Tetrapterys multiglandulosa showing: A) circular section of unstratified epidermis (bracket); B) Thick cuticle (arrowhead) and differentiated felogen (arrows). C) Median plane-convex leaf veins with malpighiaceous trichomes (arrows). D) Transverse leaf blade view of collateral bundles shaped in an open arch (egg shaped), wrapped by sclerenchyma (arrows). Leaf blade (E) with unstratified epidermis (arrow) and thick cuticle (bracket). F) Abaxial surface of leaf showing paracytic stomata (arrow) and epidermal cells with irregular contour and varied shape (asterisk). 
Table 1. Results of phytochemical analysis of aqueous and ethanol extracts of leaves and stems of Tetrapterys multiglandulosa collected in Batayporã county, MS Brazil. Tests are presented as strongly positive (100\%), moderately positive (50\%), weakly positive $(25 \%)$, partially positive $(10 \%)$, and negative (0).

\begin{tabular}{|c|c|c|c|c|}
\hline \multirow{2}{*}{ Class of secondary metabolites } & Laves & Stems & Laves & Stems \\
\hline & \multicolumn{2}{|c|}{ Aqueous extract (\%) } & \multicolumn{2}{|c|}{ Methanolic extracts (\%) } \\
\hline Phenolic compounds & 100 & 100 & 100 & 100 \\
\hline Tanins & 25 & 50 & 100 & 100 \\
\hline Flavonoids & 25 & 10 & 50 & 50 \\
\hline Free antraquinones & 10 & 25 & 0,5 & 10 \\
\hline Coumarins & 25 & 10 & 25 & 10 \\
\hline Steroids & 10 & 10 & 25 & 25 \\
\hline Triterpenes & 10 & 10 & 10 & 10 \\
\hline Heterosides cardiotonics & 55 & 30 & 50 & 30 \\
\hline Alkaloids & 30 & 10 & 25 & 10 \\
\hline
\end{tabular}

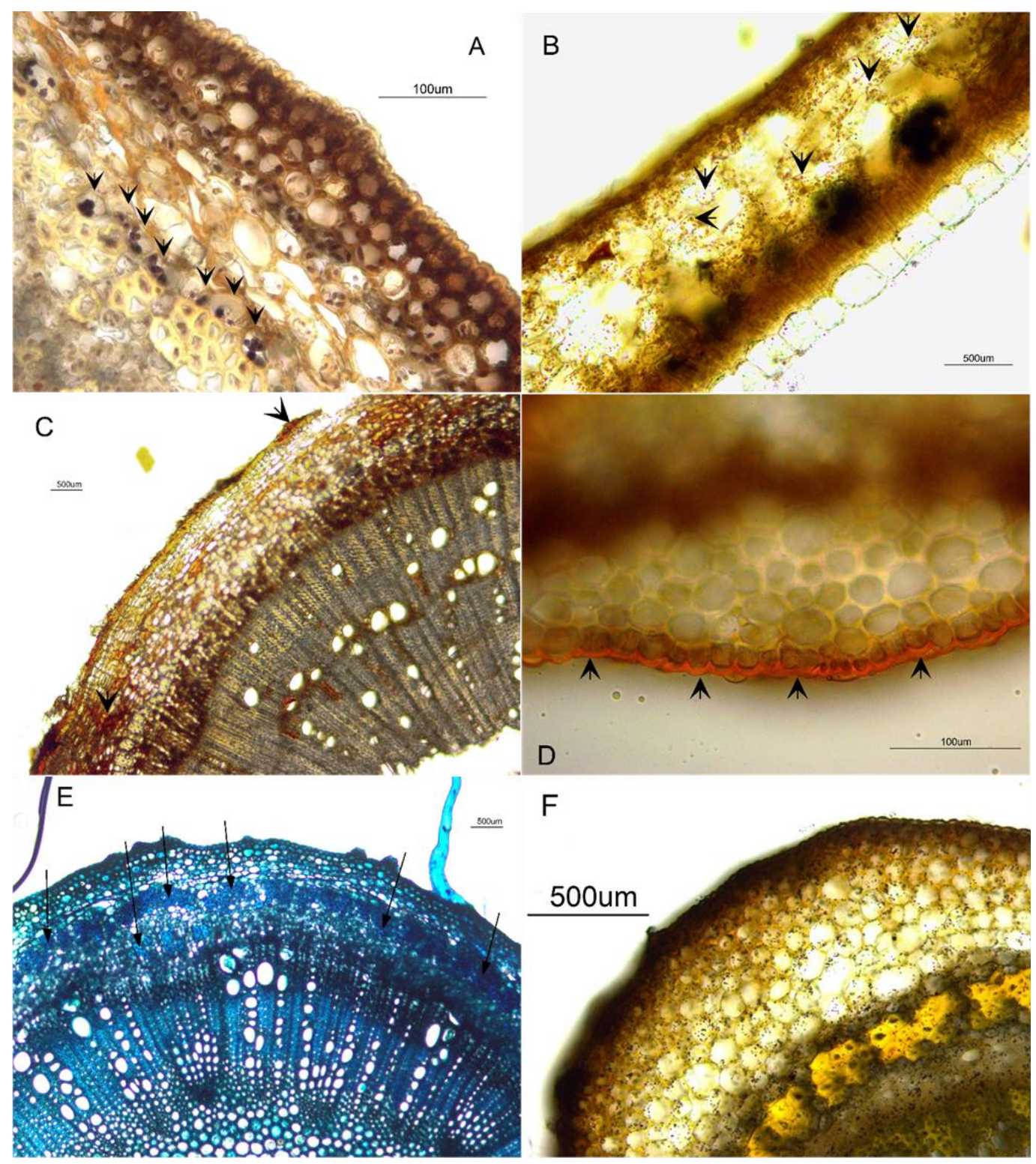

Fig 2. Light photomicrograph of stem cross-sectional histochemical tests and of leaf blade of Tetrapterys multiglandulosa. (A) Starch-Lugol, dispersed in the cortical parenchyma, forming an amiliferous sheath surrounding the vessels (arrows). (B) Phenolic compounds - Ferric chloride, (arrow) reddish granules in the phloem region and in the leaf mesophyll. (C) Lipid substances - Sudam III, reddish in cuticle and scattered in the cortex of stem (arrows). (D) Leaf - Sudam III, lipid droplets present on the cuticle and leaf border (arrow). (E) Mucilage - Methylene blue - in the cortical parenchyma of the stem (arrow). (F) Reducing sugars - Fehling - all the black spots widely distributed in all tissues and leaf glands. 
multiglandulosa (Melo and Dantas-Barros, 1999) corroborate findings of the current study. The prevalence of this metabolic compound provides evidence that ingestion of plants from this family may cause cardiac lesions.

Cardiotonic heterosides cause cardiovascular changes, and their known cellular target is the alpha subunit of the sodium $(\mathrm{Na}+)$ /potassium (K+)-ATPase (NKA), which can lead to sudden death of exposed animals (Facco et al., 2016). Further investigation should be undertaken on Tetrapterys multiglandulosa and the Malpighiaceae family, as well as its constituent chemical compounds. In addition to the significant danger they present to ruminant animals, these substances may have potential as pharmacological medications for treating cardiovascular problems.

\section{Material and Methods}

\section{Plant material}

Leaves and stems of T. multiglandulosa were collected at the São Pedro farm, in Batayporã county, MS State, (latitude 27031'71" S. and longitude 74095'99" W.) and transported to the Laboratory of Vegetable Morphology at the Anhanguera-Uniderp University in Campo Grande, MS. The specimens were conserved in $70 \%$ alcohol. Specimens were herborized, identified by Professor Eloty Justina Schleder and deposited as specimen \# 8022 at the Herbarium CGMS, Instituto de Biociências, Universidade Federal de Mato Grosso do Sul.

\section{Phytochemical analysis of leaves and stems}

Leaves and stems of T. multiglandulosa were cleaned, dried in an oven with air circulation at a temperature of 40 으, ground and stored in hermetically sealed flasks for posterior analysis.

For qualitative and quantitative phytochemical analyses, aqueous and $20 \%$ ethanol extracts were subjected to a 60 minute ultrasound bath in an Ultrasonic Cleaner, $25 \mathrm{MHz}$, $25 \stackrel{\circ}{ } \mathrm{C}$, then allowed to rest for a 24 -hour period. This process was repeated twice on consecutive days. Extracts were subjected to phytochemical assays for phenolic compounds, including tannins, flavonoids, free coumarins, anthocyanins, anthraquinones, cyanogenic glycosides, saponins, steroids and triterpenes, alkaloids and cardiotonic heterosides, following the methodology described by Matos (2009).

Analyses were repeated in triplicate, with comparison and contrast of results observing color alterations and precipitate formation in relation to controls (extract only). Color intensity and/or precipitates are indicators of the presence of elevated concentrations of secondary metabolites in botanical species. A descriptive standard for color intensity and precipitate formation described by Fontoura et al. (2015) was adopted. Reactions were identified as strongly positive $(+++=100 \%)$, moderately positive $(++=50 \%)$, weakly positive $(+=25 \%)$ and partially positive $( \pm=10 \%)$. Extracts presenting slight turbidity, minimal coloration or absence of color or absence of precipitation were identified as negative (-).

\section{Afrosimetric index}

In order to estimate the quantity of saponins present in the extract, the afrosimetric method, or "foam test" was employed (Simões et al. 2004).

\section{Histochemical analysis}

Morphoanatomical analysis of leaves and stems were performed on samples fixed after manual slicing with a trichotomy blade. For anatomical analysis, samples were treated with a $20 \%$ solution of sodium hypochlorite (Kraus and Arduin, 1997) and stain with $1 \%$ aqueous safranin and $1 \%$ Astra blue solutions in equal proportions (Kraus and Arduin, 1997), then mounted on slides with a $50 \%$ glycerin solution and analyzed under a light microscope.

Histochemical tests were performed with the following stains and reagents: Lugol for starch identification (Roth, 1964); ferric chloride for identification of phenolic compounds and tannins (Johansen,1940); Sudan III for identification of lipids (Jensen,1962); methylene blue for mucilage identification (Johansen,1940) and Fehling for determining the presence of reducing sugars (Kraus and Arduin, 1997). Samples were examined and photographed with clear field microscopy (Olympus CH3O with photographic camera Olympus PM-BP 35).

All samples studied for qualitative tests were did in triplicate and its results were recorded in specific tables. After observing the presence of secondary metabolites by qualitative methods the plant material were performed for such specific histochemical tests, also in triplicates. Eventually the results were recorded in percentage (\%) of its occurrence.

Conclusion

Analyses of leaves and stems of $T$. multiglandulosa demonstrate that the plant belongs to the Malpighiaceae Family. The plant is rich in phenolic compounds. The presence of cardiotonic heterosides is strongly associated with the incidence of mortality and abortion of cattle in Batayporã county in the state of Mato Grosso do Sul, Brasil.

\section{References}

Anderson C (2001) The identity of two water-dispersed species of Heteropterys (Malpighiaceae): $\mathrm{H}$. leona and $\mathrm{H}$. platyptera. Contributions from the University of Michigan Herbarium. 23:35-47.

Appezzato-da-glória B, Carmello-Guerreiro SM

Anatomia Vegetal, 3nd edn. Viçosa, Minas Gerais.

Carvalho GD, Nunes LC, Bragança HBN, Porfírio LC (2009) Principais plantas tóxicas causadoras de morte súbita em bovinos no Estado do Espírito Santo - Brasil. Arch Zootec. 58:87-98.

Carvalho MN, Alonso LA, Cunha TG, Revedutti J, Barros CSL, Lemos RAA (2006). Intoxicação de bovinos por Tetrapterys multiglandulosa (Malpighiaceae) em Mato Grosso do Sul. Pesqui Vet Brasil. 26:139-146.

Castro AHF, Paiva R, Alvarenga AA, Vitor SMM (2009) Calogênese e teores de fenóis e taninos totais em barbatimão (Stryphnodendron adstringens (Mart. Coville). Cienc Agrotec. 33:385-390. 
Coelho MFB, Spiller C (2008) Fenologia de Heteropterys aphrodisiaca O. Mach. - Malpighiaceae, em Mato Grosso. Rev Bras Plantas Med. 10:1-7.

Facco GG, Muller JAI, Matias R, Barbosa-Ferreira M, Correa BO, Bono JAM, Dourado DM, Fernandes CES (2016) Antifungal potential and phytochemistry of Tetrapterys multiglandulosa CAV aerial parts. Biosci J. 32:1586-1594.

Fontoura FM, Matias R, Ludwig J, Oliveira AKM, Bono JAM, Martins PFRB, Corsino J, Guedes NMR (2015) Seasonal effects and antifungal activity from bark chemical constituents of Sterculia apetala (Malvaceae) at Pantanal of Miranda, Mato Grosso do Sul, Brazil. Acta Amazon. 45:283-292.

Jensen WA (1962) Botanical histochemistry. H. H. Friman \& Co. 1nd edn. San Francisco.

Johansen DA (1940) Plant microtechnique and microscopy. Mc Graw Hill Book. 1nd edn. New York.

Kraus JE, Arduin M (1997) Manual básico de métodos em morfologia vegetal. Seropédica, 1nd edn. Brasil.

Mamede MCH (1993) Anatomia dos órgãos vegetativos de Camarea (Malpighiaceae). Acta Bot Bras. 7:3-19.

Matos JFA (2009) Introdução a Fitoquímica Experimental. 3nd edn, Fortaleza.

Melo MM, Vasconcelos AC, Dantas GC, Alzamora Filho F (2001) Experimental intoxication of pregnants goats with Tetrapterys multiglandulosa A. Juss. (Malpighiaceae). Arq Bras Med Vet Zoo. 53:58-65.

Melo MM, Dantas-Barros AM (1999) Triagem fitoquímica preliminar de Tetrapterys multiglandulosa A. Juss. (Malpighiaceae). Rev Bras Toxicol. 12:55-62.

Nascimento MS, Habermehl GG (1995) Two naphto-pyrone glycosides from Mascagnia rigida. Fitoterapia. 46:539-542.
Pott A, Pott VJ, Souza TW (2006) Plantas daninhas de pastagem na região dos Cerrados. Embrapa Gado de Corte, 1nd edn, Campo Grande.

Rodríguez $M$, Hasegawa $M$, González-Mújica $F$, Motta $N$, Castillo A, Castillo J, Zea E, Mora K, Sousa L, González A, Camejo D (2008) Antidiabetic and antiradical activities of plants from Venezuelan Amazon. Rev Bras Farmacogn. 18:331-338.

Roth I. (1964) Microtecnica Vegetal. 1nd edn. Universidade Central da Venezuela, Caracas.

Santana MM, Silva KLF (2013) Anatomia e histoquímica de folhas e elaióforos de Byrsonima coccolobifolia (malpighiaceae). Paper presented at 64th Congresso Nacional de Botânica, Belo Horizonte, 10-15 november 2013.

Simões CMO, Schenkel EP, Gosmann G, Mello JCP, Mentz LA, Petrovick PR (2004) Farmacognosia da Planta ao medicamento. 5nd edn. Porto Alegre.

Souza RIC, Santos AC, Sá Ribas NLK, Colodel EM, Leal PV, Pupin RC, Carvalho NM, Lemos RAA (2015) Doenças tóxicas de bovinos em Mato Grosso do Sul. Sem-Cien Agrar. 36:1355-1368.

Souza VC, Lorenzi H (2012) Botânica Sistemática: guia ilustrado para identificação das famílias de Fanerógamas nativas e exóticas no Brasil, baseado em APG III. 3nd edn. Instituto Plantarum. São Paulo.

Tokarnia CH, Döbereiner JD, Peixoto PV (2002) Poisonous plants affecting livestock in Brazil. Toxicon. 40:1635-60.

Torres LF (2013) Avaliação do potencial embriogênico de suspensões celulares de Coffea arábica. 111 p. Dissertation, Universidade Federal de Lavras, Lavras-MG. 